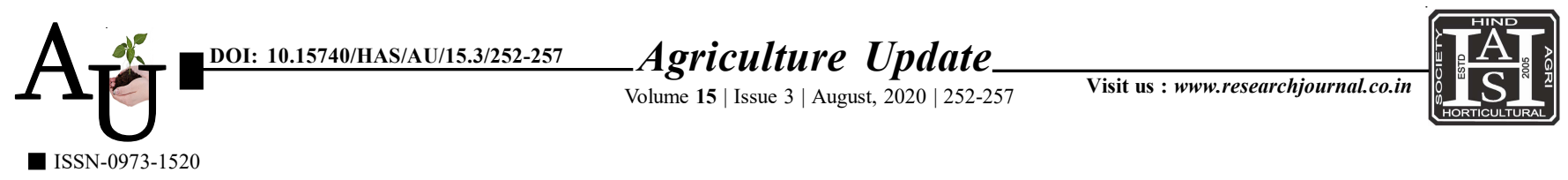

\title{
Research Article: Management orientation of young awardee farm women of University of Agricultural Sciences, Dharwad
}

Article Chronicle: Received :

23.05.2020;

Revised:

22.06.2020;

Accepted :

23.07.2020

KEY WoRDS:

Management orientation, Farm women, Yuva shresta krishi mahile
Author for correspondence :

\section{Suma Balambeed}

Department of Extension and Communication Management College of Community Science,

University of Agricultural

Sciences Dharwad

(Karnataka) India

Email: Sumab1170@gmail

$$
\text { .com }
$$

See end of the article for

authors' affiliations
SUMMARY : Since ancient times women have been playing a crucial role in family as well as in farming. But their contribution has not been identified fully and acknowledged. In the present scenario of globalization, liberalization and privatization of agricultural sector, the sustainable development of farm women is considered as a key factor for development of any country. This study was conducted in Dharwad, Gadag and Haveri districts of Karnataka. The woman who had received Yuva Shresta Krishi Mahile award during 2014-2017 was purposively selected. A total of 60 young awardee farm women were selected as a sample for the study from 17 talukas conferred by the UAS Dharwad. Pre-structured interview schedule was used to collect the data. Suitable statistical tools like frequency, percentage and indices were used for analysis of the data. The important findings of the study revealed that, cent per cent of the awardee farm women belonged to young age group $(<35$ years $)$ had high school education and from big family size (43.33\%) belonged to joint family $(51.67 \%)$, had medium farming experience $(60.00 \%)$ and had big land holding (38.33\%). A majority of the respondents had low annual income (78.33\%), 63.34 per cent had high level management orientation, 33.33 per cent had medium level and only 3.33 per cent had low level of management orientation.

How to cite this article : Balambeed, Suma and Channal, Geeta P. (2020). Management orientation of young awardee farm women of University of Agricultural Sciences, Dharwad. Agric. Update, 15(3): 252-257; DOI : 10.15740/HAS/AU/15.3/252-257. Copyright@2020: Hind Agri-Horticultural Society. 